\title{
13. DATING OF OCEAN CRUST HYDROTHERMAL ALTERATION: STRONTIUM ISOTOPE RATIOS FROM HOLE 504B CARBONATES AND A REINTERPRETATION OF Sr ISOTOPE DATA FROM DEEP SEA DRILLING PROJECT SITES 105, 332, 417, AND 4181
}

\author{
Hubert Staudigel, Scripps Institution of Oceanography and Lamont-Doherty Geological Observatory of \\ Columbia University \\ and \\ Stanley R. Hart, Center for Geoalchemy, Massachusetts Institute of Technology ${ }^{2}$
}

\begin{abstract}
Recent revisions of the geological time scale by Kent and Gradstein (in press) suggest that, on the average, Cretaceous magnetic anomalies are approximately 10 m.y. older than in Larson and Hilde's (1975) previous time scale. These revised basement ages change estimates for the duration of alteration in the ocean crust, based on the difference between secondary-mineral isochron ages and magnetic isochron-crustal ages, from 3 to approximately 13 m.y.

In addition to the revised time scale, Burke et al.'s (1982) new data on the temporal variation of ${ }^{87} \mathrm{Sr} /{ }^{86} \mathrm{Sr}$ in seawater allow a better understanding of the timing of alteration and more realistic determinations of water/rock ratios during seawater-basalt interaction. Carbonates from all DSDP sites which reached Layer 2 of Atlantic crust (Sites 105, 332, 417 , and 418 ) are deposited within $10-15 \mathrm{~m} . \mathrm{y}$. of crustal formation from solutions with ${ }^{87} \mathrm{Sr} /{ }^{86} \mathrm{Sr}$ ratios identical to unaltered or contemporaneous seawater. Comparisons of the revised seawater curve with the ${ }^{87} \mathrm{Sr} /{ }^{86} \mathrm{Sr}$ of basement carbonates is consistent with a duration of approximately $10-15 \mathrm{~m}$.y. for alteration in the ocean crust.

Our preliminary $\mathrm{Sr}$ and ${ }^{87} \mathrm{Sr} /{ }^{86} \mathrm{Sr}$ data for carbonates from Hole $504 \mathrm{~B}$, on 5.9-m.y.-old crust south of the Costa Rica Rift, suggest that hydrous solutions from which carbonates precipitated contained substantial amounts of basaltic $\mathrm{Sr}$. For this reason, carbonate ${ }^{87} \mathrm{Sr} /{ }^{86} \mathrm{Sr}$ cannot be used to estimate the duration of alteration at this site. A basalt-dominated alteration environment at Hole 504B is consistent with heat-flow evidence which indicates rapid sediment burial of crust at the Costa Rica Rift, sealing it from access by seawater and resulting in unusually low water/rock ratios during alteration.
\end{abstract}

\section{INTRODUCTION}

Newly formed, hot oceanic lithosphere is cooled by thermally driven seawater convection systems. Circulating seawater interacts with the oceanic crust, altering its chemical composition, and returns to the ocean as a hydrothermal solution. Altered oceanic crust is at some later time "recycled" into the mantle by subduction. This geochemical cycle has three effects of global significance:

1. The interaction of seawater with basalt changes the bulk composition of oceanic crust prior to subduction; this altered crust may contribute to the generation of magma at destructive plate margins and to mantle heterogeneities.

2. Hydrothermal processes in the oceanic crust are responsible for the formation of exhalative sulfide deposits.

3. Hydrothermal reactions between seawater and basalt affect the concentration and isotopic composition of many elements in seawater.

To quantitatively evaluate these processes, it is of great importance to determine the duration and the bulk geochemical fluxes of ocean crust alteration at various ages of crustal maturation. DSDP Hole 504B is important in

\footnotetext{
${ }^{1}$ Anderson, R. N., Honnorez, J., Becker, K., et al., Init. Repts. DSDP, 83: Washington (U.S. Govt. Printing Office).

2 Addresses: (Staudigel) Scripps Institution of Oceanography A-015, University of California at San Diego, La Jolla, CA 92093; (Hart) Center for Geoalchemy, Massachussetts Institute of Technology, Cambridge, MA 02139.
}

the discussion of these problems because of its unusual depth of penetration, high temperatures of alteration, and the high sedimentation rates that limited access of water to the crust sooner after formation than at most other ridges. Hole 504B was drilled in young crust generated at a mid-ocean ridge with intermediate spreading rate. It is, therefore, complementary to the majority of DSDP holes from the Atlantic, the focus of most previous alteration studies (e.g., Hole 332B, Andrews, 1977; Hole 396B, Böhlke et al., 1980; Sites 417 and 418, Alt and Honnorez, 1984; Donnelly, Francheteau, Bryan, Robinson, Flower, Salisbury, et al., 1980).

In this paper, we will review geochemical and geophysical evidence for the duration of alteration, and we will discuss some preliminary data for Hole 504B carbonates. The most important findings are that (1) alteration at Hole 504B occurred under rather low water/ rock ratios which makes dating of secondary phases difficult or impossible, and (2) precipitation of secondary phases in Atlantic crust probably lasted about $13 \pm$ 5 m.y., somewhat longer than previously estimated (Hart and Staudigel, 1978, 1983; Richardson et al., 1980). Vein mineral deposition at Hole 504B has probably stopped very recently or might still be in its waning stage.

\section{DURATION OF OCEAN CRUST ALTERATION}

A number of physical and chemical observations can be interpreted in terms of the duration of ocean crust alteration. Physical observations include heat-flow measurements, change in seismic velocities, the magnetic in- 
tensity of the crust, and the occurrence of hydrothermal springs, such as the "black smokers." Chemical observations include the degree of alteration found in crust of different ages, dating of secondary phases by radiogenic isotope systematics, and chemical gradients found in interstitial waters of sediments overlying basaltic crust of various ages. In this section, we will discuss these different types of evidence. Dating of secondary phases by radiogenic isotope systematics is treated in the following sections.

Two different interpretations of heat-flow measurements document convective, hydrothermal heat loss from the oceanic crust. The largest amount of convective heat loss is reflected indirectly in the unexpectedly low conductive heat flow measured near or at mid-ocean ridges (e.g., Lister, 1972; Sclater et al., 1974, 1976; Anderson and Hobart, 1976; Becker and Von Herzen, 1983). Substantially smaller amounts of convective heat loss presumably cause the concave or convex temperature profiles observed in crust up to $55 \mathrm{~m}$.y. old in the Crozet basin (Anderson et al., 1979). Late advection of heat into the ocean reservoir is also accompanied by chemical transport, as suggested by $\delta^{18} \mathrm{O}$ and $\mathrm{Ca}^{2+}$ concentration profiles in interstitial waters in sediments on crust up to 120 m.y. old (Lawrence and Gieskes, 1981). The geochemical fluxes involved in this process are negligible for most elements, but they are significant for the fluxes in oxygen (Gieskes and Lawrence, 1981; Lawrence and Gieskes, 1981; McDuff, 1981).

These data suggest strongly that thermally driven flow of hydrous solutions occurs both in young and in old crust. However, it is impossible to make realistic quantitative, integrated, bulk estimates of this fluid flow either in young or in old oceanic crust. These difficulties are related to the large regional scatter in the heat-flow measurements, the model-dependence of the calculated heat flow, the uncertainty in the theoretical, predicted heat flow from lithospheric cooling models, and the occurrence of basaltic material in ash layers of Layer 1. In addition to this inability to quantify hydrothermal flow it is not entirely clear how the convective flow patterns are created. Theoretically, they can be caused by convection cells in an isotropic, permeable Layer 1 and/or Layer 2 of the oceanic crust or, alternatively, by hydrous flow along very restricted aquifers. The latter is probably more likely, but this makes it even more difficult to evaluate the total exchange rates between the oceanic crust and seawater.

Houtz and Ewing (1976) subdivided the oceanic Layer 2 into three seismically distinct layers, an upper layer, $2 \mathrm{~A}$, with lower velocities, and two deeper layers, $2 \mathrm{~B}$ and $2 \mathrm{C}$, with higher velocities. Layer $2 \mathrm{~A}$ shows decreasing thickness with increasing crustal age, pinching out at an age of approximately 70 m.y. in the Atlantic. Such an increase in seismic velocity of the upper Layer 2 is best explained by sealing of fractures and voids during aging of the oceanic crust. This closure could be a result of vein mineral deposition and/or compaction by the sedimentary overburden, and may include nearly isochemical diagenetic reactions which have little or no signifi- cant effect on the total balance of exchange reactions between seawater and the oceanic crust.

The bulk magnetic intensity of Layer 2 decreases exponentially with crustal age; in the Atlantic Ocean, approximately $95 \%$ of the magnetic intensity of basalt has decayed after only 5 m.y. of alteration (Hall and Robinson, 1979). This decay in bulk magnetization probably reflects the oxidation of titanomagnetite, suggesting that this process may be nearly complete after about $5 \mathrm{~m}$.y.

Constraints for the duration of alteration, based on comparisons of petrographic and/or chemical signs of alteration in basalts of different age, entail a number of problems. The most important problem is the generally poor recovery of alteration materials during drilling, particularly in young crust (it is substantially better in old crust). Therefore, averaged data from holes drilled in crust of different age cannot be meaningfully compared. Alteration-related comparisons of materials with different ages should be restricted to identical lithological rock types with similar textures. For example, from visual observation it is clear that the colors of massive basalts younger than $10 \mathrm{~m} . \mathrm{y}$. are dominated by grey, black, and white, whereas older basalts are usually green and brown, indicative of higher degrees of pervasive alteration with age. Water contents of basalts from DSDP Hole 332B suggest that hydration is not completed in 3.2-m.y.-old crust, whereas deep portions of 120-m.y.-old Hole 418A show indications of dehydration (Staudigel, Richardson, et al., 1981; Staudigel, Muehlenbachs, et al., 1981). These comparisons show that the aging of bulk rocks includes a number of different processes which are difficult to tie into a rigid temporal framework and are not necessary unidirectional.

It seems surprising that fresh glass, which is extremely susceptible to alteration under hydrous conditions, can be preserved even in very old crust, such as in the 120m.y.-old DSDP Hole 418A (e.g., Donnelly, Francheteau, Bryan, Robinson, Flower, Salisbury, et al., 1980). This probably is best explained by very heterogeneous alteration, whereby some portions of the crust are very efficiently sealed off from access by seawater, while other portions may stay in contact with seawater. Such contact can be achieved via highly permeable zones, either horizontal layers of fractured or brecciated basalt or vertical faults through basalt and sediments.

The most spectacular manifestation of ocean-floor hydrothermal activity probably is the occurrence of white and black smokers at the Galapagos rift (e.g., Corliss et al., 1979) and at $21^{\circ} \mathrm{N}$ (Edmond et al., 1982), respectively, or other hydrothermal vents observed on the ocean floor. However, emission of hydrothermal solutions from "normal" oceanic crust (seamounts excluded) is restricted to the near-axis area (e.g., Lonsdale, 1977; Crane and Ballard, 1980), which may indicate that most hightemperature reactions occur only in crust younger than a few million years.

One of the biggest problems in deriving a coherent interpretation of this evidence is that, taken alone, each observation reflects a different process or a different aspect of hydrothermal systems in the oceanic crust. The 
most important task before us now is to link the independent observations by relating, for example, the chemical fluxes to the heat fluxes, or the precipitation of secondary phases to the changes in seismic velocity. So far there have been two approaches to this goal:

1. The total volume of heat lost through black-smokertype vents can be constrained in two different ways. One is to calculate the total amount of water needed to explain the convective heat loss at mid-ocean ridges, and the other is to estimate how much fluid from hot springs is required to explain the ${ }^{3} \mathrm{He} /{ }^{4} \mathrm{He}$ anomaly found across a mid-ocean ridge (e.g., the Galapagos rift, Jenkins et al., 1978). Both estimates show reasonable agreement, suggesting that the hot springs like the ones at Galapagos (Edmond, Measures, McDuff, et al., 1979; Edmond, Measures, Magnum, et al., 1979) or $21^{\circ} \mathrm{N}$ (Edmond et al., 1982) may in fact be responsible for the majority of the heat loss (and chemical fluxes) at mid-ocean ridges. This in turn provides a correlation of convective heat loss and chemical exchange rates between the oceans and basalt. Based on this correlation, Edmond, Measures, McDuff, et al. (1979) calculated total exchange rates between the ocean and basalt for a large number of elements. However, Hart and Staudigel (1982) and Staudigel and Hart (1983) pointed out that, at least for the alkali metals $\mathrm{K}$ and $\mathrm{Rb}$, these fluxes are unreasonable according to the estimated ocean-crust inventories, thus questioning the suggested correlation of heat flow and some chemical fluxes. This contradiction convincingly demonstrates biases between two independent observations. Whereas Edmond and others (1979) demonstrate that hot springs in fact cause a major chemical flux of alkalis from the ocean crust into seawater, of the same order of magnitude as the river fluxes, Hart and Staudigel's (1982) chemical balance reflects the bulk flux between the oceanic crust and seawater, which consists both of the fluxes from the crust into the ocean, in the form of hydrothermal springs, and the fluxes from seawater into the oceanic crust, which are not reflected in Edmond, Measures, McDuff, et al.'s (1979) estimates. The latter is consistent with the suggestion by Mottl (1983) that the black smoker heat fluxes are not steadystate and that the fluxes of Edmond, Measures, McDuff, et al., 1979, are too high by a factor of about ten.

2. Dating of secondary phases from veins in the oceanic crust allows a correlation of absolute ages with the petrographically observed sequence of vein mineral deposition (Hart and Staudigel, 1978, 1983; and Richardson et al., 1980; Staudigel, Richardson, et al., 1981; Staudigel, Muehlenbachs, et al., 1981). This, in turn, allows a correlation with a number of geophysical observations which are apparently functions of crustal age, such as the heat flow or the bulk magnetic intensity. The significance of isotopic dating is discussed later in this paper in connection with our data from Hole 504B.

\section{TECHNIQUES}

We analyzed vein carbonates from Hole 504B and fish debris samples from the Pacific Ocean for $\mathrm{Sr}$ concentration by isotope dilution and for ${ }^{87} \mathrm{Sr} /{ }^{86} \mathrm{Sr}$ (Table 1). Carbonates selected from Hole 504B were taken only from veins $>1 \mathrm{~mm}$ thickness. They were separated from the host rock, and gently crushed to a grain size sufficiently small to
Table 1. Sr concentration and isotope ratios of carbonates from DSDP Hole 504B and fish debris samples from Indian and Pacific Ocean sediments.

\begin{tabular}{llcc}
\hline $\begin{array}{l}\text { Sample number } \\
\text { (interval in cm) }\end{array}$ & Identification & $\mathrm{Sr}(\mathrm{ppm})$ & ${ }^{87} \mathrm{Sr} /{ }^{86} \mathrm{Sr}$ \\
\hline 504B-4-5, 12-20 & Aragonite & 1658 & $0.70866 \pm 5$ \\
504B-80-2, 52-54 & Calcite & 28.9 & $0.70411 \pm 5$ \\
504B-80-2, 72-80 & Calcite & 23.3 & $0.70414 \pm 5$ \\
DODO 37P, 440-480 & Fish debris & 1431 & $0.70874 \pm 4$ \\
$6^{\circ} \mathrm{N}, 165^{\circ} 55^{\prime} \mathrm{E}$ & 15-17 m.y. & & \\
DODO $108 \mathrm{P}, 130-170$ & Fish debris & 1480 & $0.70784 \pm 3$ \\
$19^{\circ} 26^{\prime} \mathrm{S}, 80^{\circ} 59^{\prime} \mathrm{E}$ & 36-39.5 m.y. & & \\
\hline
\end{tabular}

Note: ${ }^{87} \mathrm{Sr} /{ }^{86} \mathrm{Sr}$ data are normalized to Eimer and Amend Sr-carbonate $=0.7080$; errors are given for last significant figure. Fish debris samples courtesy of P. Doyle (Scripps Institution of Oceanography). Locations of fish debris samples and their approximate age, after P. Doyle, are also given.

provide a large fraction of monomineralic grains (usually less than $100 \mu \mathrm{m}$ in size). Carbonates were hand-picked from these materials under a binocular microscope. All samples were repeatedly checked for purity; mineral identifications by X-ray diffraction were carried out before isotope analysis. Fish debris samples were separated by $\mathbf{P}$. Doyle (Scripps Institution of Oceanography), using heavy liquid separation techniques and subsequent hand picking under a binocular microscope. Only fish teeth were included in these separates. Fish debris samples were washed in $\mathrm{H}_{2} \mathrm{O}_{2}$ and in acetic acid to remove surface coatings; the final teeth samples appeared colorless and were free of surface coating.

Carbonates from Hole 504B were analyzed at M.I.T. using techniques described in Hart and Brooks (1974). The fish debris samples were analyzed at Lamont-Doherty Geological Observatory with techniques similar to the ones used at M.I.T. Details of the mass spectrometric techniques at Lamont are outlined in Zindler et al. (in press).

\section{THE DURATION OF VEIN MINERAL DEPOSITION IN THE OCEANIC CRUST}

There are two possible ways to date the duration of precipitation of secondary phases in the oceanic crust using ${ }^{87} \mathrm{Rb}^{87} \mathrm{Sr}$ isotope systematics (Hart and Staudigel, 1978). One method is based on the isochronous relationships displayed by secondary phases. The difference between the age of the secondary-mineral isochron and the crustal age based on magnetic lineations at a given location constrains the duration of vein mineral deposition. The second method of dating uses the observation that most vein carbonates in the oceanic crust are apparently deposited from unaltered seawater. A comparison of the temporal variation of ${ }^{87} \mathrm{Sr} /{ }^{86} \mathrm{Sr}$ in seawater and the carbonate ${ }^{87} \mathrm{Sr} /{ }^{86} \mathrm{Sr}$ constrains the age of carbonate precipitation. Both methods rely on the analytical precision of the $\mathrm{Rb}-\mathrm{Sr}$ isotope systematics in the secondary phases; the first method also depends upon the accuracy of the geomagnetic reversal time scale which provides the age information for the basement, and the second method upon the accuracy of the temporal variation of ${ }^{87} \mathrm{Sr} /{ }^{86} \mathrm{Sr}$ in seawater. Recently, both the magnetic time scale and the temporal variation of ${ }^{87} \mathrm{Sr} /{ }^{86} \mathrm{Sr}$ in seawater have been substantially revised (Kent and Gradstein, in press; Burke et al., 1982), making a reinterpretation of previous isotope data necessary (Hart and Staudigel, 1978; 1983; Richardson et al., 1980).

Currently, there are two published $\mathrm{Rb}-\mathrm{Sr}$ secondarymineral isochrons, one from DSDP Sites 417 and 418 in the northwestern Atlantic (Hart and Staudigel, 1978; 
Richardson et al., 1980) and one from DSDP Hole 516F on the Rio Grande Rise (Hart and Staudigel, 1983). Based on the observed range in $\mathrm{Rb} / \mathrm{Sr}$ ratios in secondary phases from the oceanic crust and the minimum duration of alteration, which is usually longer than 5 m.y., it appears unlikely that alteration phases from the 5.9-m.y.-old crust in Hole 504B can be dated using $\mathrm{Rb} / \mathrm{Sr}$ isotope systematics. In Figure 1, we have plotted published isochron ages versus revised crustal magnetic anomaly ages after Kent and Gradstein (in press) for DSDP Holes 417A, $418 \mathrm{~A}$, and $516 \mathrm{~F}$. The sizes of the boxes reflect the precision of the isochron age and the uncertainty in the magnetic anomaly age. Within these uncertainties, alteration at Sites 417 and 418 may have stopped very soon after formation of the crust or could have lasted up to $23 \mathrm{~m}$.y. At Hole 516F, alteration lasted for at least $12 \mathrm{~m} . \mathrm{y}$. and at most for $23 \mathrm{~m} . \mathrm{y}$. This long duration at Site $516 \mathrm{~F}$ may or may not be "typical" for oceanic crust because of the evidence for off-ridge volcanism on the Rio Grande Rise, in the form of ash layers interbedded with the overlying sediments and a submarine volcaniclastic flow (Hart and Staudigel, 1983; Fodor and Thiede, 1977). Such an offridge volcanic event may have had its own hydrothermal convection system, accompanied by deposition of secondary phases. However, the implied duration of alteration in Hole $516 \mathrm{~F}$ is in general agreement with the revised age of alteration at Site 417 , so that the age of the vein minerals in Hole $516 \mathrm{~F}$ may very well be related to the hydrothermal convection systems on the ridge. If the latter is correct, the average duration of hydrothermal alteration at these two sites is about $13 \pm 5$ m.y.

Ages of carbonates precipitated from seawater from DSDP Holes 105, 332B, 417, and 418 were estimated as follows. We plotted the ${ }^{87} \mathrm{Sr} /{ }^{86} \mathrm{Sr}$ of carbonates analyzed

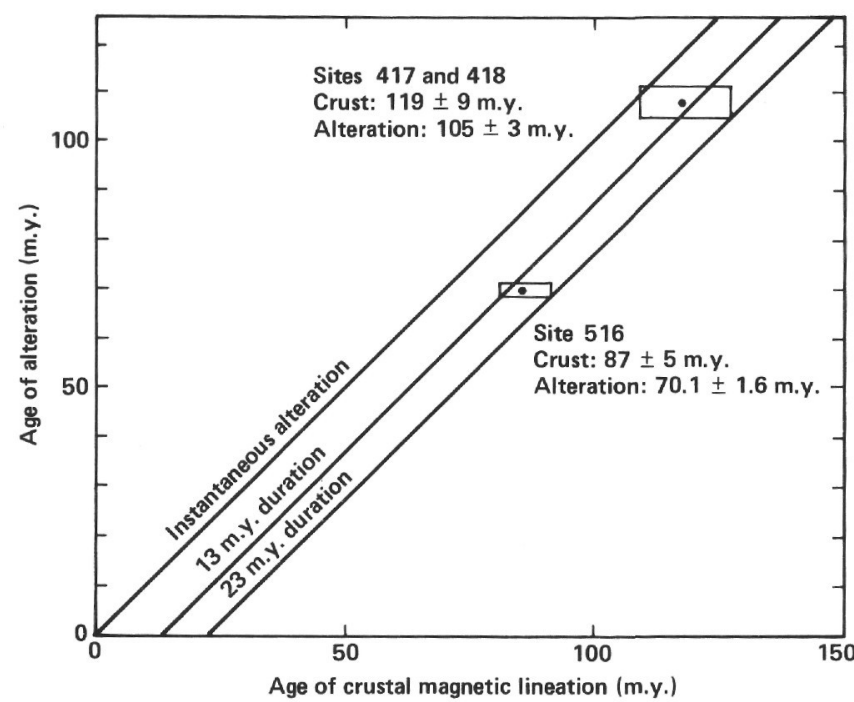

Figure 1. Age of crustal magnetic lineations versus the age of alteration based on secondary-mineral isochron ages for DSDP Sites 417, 418 and 516 (Richardson et al., 1980; Hart and Staudigel, 1983). The size of each box is determined by the error of the age of the magnetic anomaly and of the isochron date for that site. For comparison, lines characteristic of instantaneous alteration (crustal age $=$ alteration age) and for alteration continuing until 13 m.y. and $23 \mathrm{~m}$.y. after crustal formation are plotted. by Hart and Staudigel (1978) and Richardson et al. (1980), together with the ${ }^{87} \mathrm{Sr} /{ }^{86} \mathrm{Sr}$ of the $504 \mathrm{~B}$ carbonates, on the seawater ${ }^{87} \mathrm{Sr} /{ }^{86} \mathrm{Sr}$ curve of Burke et al. (1983; Fig. 2). In this diagram, we have also plotted the ${ }^{87} \mathrm{Sr} /{ }^{86} \mathrm{Sr}$ isotope ratios of two marine phosphates (fish debris). Carbonates, as analyzed by Burke et al. (1982), may be subject to diagenetic reactions which change their chemical and isotopic signature (Elderfield and Gieskes, 1982). Since much of the $\mathrm{Sr}$ in fish teeth is fixed in apatite, the ${ }^{87} \mathrm{Sr} /{ }^{86} \mathrm{Sr}$ ratios of fish teeth provide an independent check on the temporal variation of seawater ${ }^{87} \mathrm{Sr} /{ }^{86} \mathrm{Sr}$. Our data, although slightly higher than the mean of Burke et al.'s (1982) data, fall within a range of \pm 0.0001 . This may represent a reasonable estimate of the accuracy of the Burke et al. (1982) curve.

By comparison with the mean of this curve, alteration at Site 105 lasted about 10-1.5 m.y., in agreement with the time interval obtained from the celadonites in Figure 1. At Sites 417 and 418, alteration may also have lasted for a relatively short time, but because of the sinusoidal character of the seawater curve between 80 and 130 m.y., the best limit which can be placed on the duration of alteration is about 40 m.y. Hole 332B carbonates show an $\mathrm{Sr}$ isotope ratio of 3.2 m.y. or younger seawater, but alteration may also be continuing at this site. The ${ }^{87} \mathrm{Sr} /{ }^{86} \mathrm{Sr}$ of vein carbonates from Hole $504 \mathrm{~B}$ is substantially lower than that of seawater at any time in the lifetime of the ocean crust, showing that these carbonates were not deposited from seawater with an unaltered ${ }^{87} \mathrm{Sr} /{ }^{86} \mathrm{Sr}$ ratio. This has two implications: (1) Sr isotope ratios of carbonates from this site cannot be used to in-

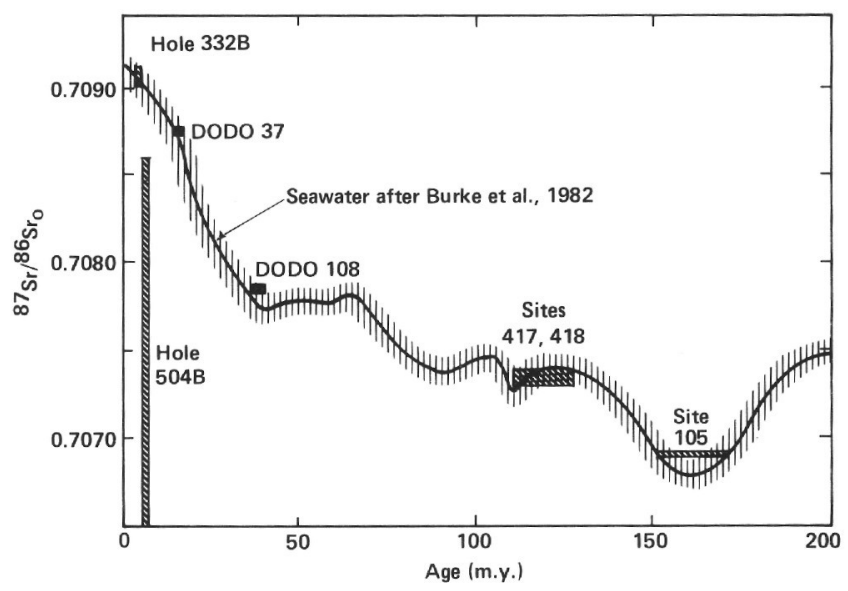

Figure $2 .{ }^{87} \mathrm{Sr} /{ }^{86} \mathrm{Sr}$ of carbonates from DSDP Holes 105, 332B, 417, 418 , and 504B, and two marine phosphates (after Hart and Staudigel, 1978, 1983; Richardson et al., 1980; and this study). For reference, we have shown the time variation of ${ }^{87} \mathrm{Sr} /{ }^{86} \mathrm{Sr}$ (after Burke et al. 1982; absolute ages after Kent and Gradstein, in press). The size of each box for Sites 105, 417, and 418 and Hole 332B is determined by the range $(2 \sigma)$ of the observed variation in ${ }^{87} \mathrm{Sr} /{ }^{86} \mathrm{Sr}$ at a given site and the error in basement age assigned by Kent and Gradstein (in press). Note that the error given for the crustal age is related to the uncertainty in the biostratiographic age of the seawater curve so that the relative error to the $\mathrm{Sr}$ curve is smaller than the error indicated on an absolute age scale. Estimates for the duration of seawater alteration should be estimated from the mean of the crustal age to the corresponding value on the seawater curve. 
fer their precipitation age and (2) alteration solutions in Hole 504B had unusually large amounts of dissolved basaltic Sr. The first point strongly suggests the need for proper documentation of the unaltered character of carbonate-precipitating solutions before this technique can be applied to dating of vein mineral deposition. The amount of basaltic $\mathrm{Sr}$ is about $8 \%$ in carbonate Sample 504B-4-5, 12-20 cm and $81 \%$ in Samples 504B-80-2, $52-54 \mathrm{~cm}$ and 504B-80-2, 72-80 cm, based on their $\mathrm{Sr}$ isotope ratios in Table 1. This large, dissolved, "basaltic" component in hydrous solutions in Hole 504B also is reflected in the low $\mathrm{Sr}$ concentration of these carbonates: carbonates in equilibrium with a solution with a basaltic $\mathrm{Sr} / \mathrm{Ca}$ ratio should have $\mathrm{Sr}$ concentrations of $15-45 \mathrm{ppm}$ Sr [assuming a ${ }^{*} \mathrm{~K}_{\mathrm{D}}(\mathrm{Sr} / \mathrm{Ca})$ in the range of 0.05 and 0.15; Kinsman and Holland, 1969; Katz and Matthews, 1977; Baker et al., 1982]. The Sr concentrations of the two deepest calcites, 23 and $29 \mathrm{ppm} \mathrm{Sr}$, respectively, are within this range. Calcites deposited directly from seawater should have much higher $\mathrm{Sr}$ concentrations (300-500 ppm), as was found in most of the calcites from Holes 105, 332B, 417A, and 418A.

\section{DISCUSSION AND CONCLUSIONS}

We have addressed two problems in this paper: (1) we have evaluated current geophysical and geochemical evidence regarding the duration of alteration in the oceanic crust, and (2) we have presented data for $\mathrm{Sr}$ isotope systematics of carbonates from DSDP Hole 504B. These data cannot be used to date alteration in Hole 504B, but they do suggest unusually low water/rock ratios.

A number of characteristics of secondary-mineral isochrons have to be evaluated before the significance of these data can be discussed. Secondary-mineral isochrons generally include only layer silicates with high $\mathrm{Rb} / \mathrm{Sr}$ ratios, such as celadonites. Based on petrographic observations, celadonites are formed early in the alteration of the oceanic crust (e.g., Bass, 1976; Donnelly, Francheteau, Bryan, Robinson, Flower, Salisbury, et al., 1980; Staudigel, Richardson, et al., 1981; Alt, in press), which might suggest that these isochron ages are significant only for the beginning of alteration. However, this appears to be unlikely, since celadonites, just as many other layer silicates, may take up alkalis for a long time, when they are in contact with seawater (Elderfield, 1976). Similarly, zeolites have a high ion exchange capacity and continue to exchange with circulating solutions after their formation. Thus celadonites and analcite are not "closed" with respect to their $\mathrm{Rb} / \mathrm{Sr}$ isotope systematics until seawater circulation ends. This interpretation is supported by the observation that carbonates yield precipitation ages in the same range as the isochron ages, even though petrographic evidence shows that carbonate precipitation usually postdated celadonite formation.

Thus, based on the currently published data, formation of secondary phases lasts approximately $13 \pm 5 \mathrm{~m}$.y. The observed range of approximately $10 \mathrm{~m}$.y. probably reflects different processes and different sedimentation rates which are responsible for burial and sealing of a site. For example, the breakdown of titanomagnetites may be nearly completed at approximately 5-8 m.y. where- as celadonites might exchange with seawater for somewhat longer time. However, it should be emphasized that the amount of radiogenic isotope data available is still limited and more work is necessary to constrain the duration of alteration.

The timing of the major phase of secondary-mineral deposition closely follows the decay of the heat-flow anomaly at mid-ocean ridges, suggesting that rapid circulation of water is the main factor controlling deposition of large quantities of secondary phases. This implies that, at sites with high sedimentation rates, rapid deposition of vein minerals may terminate earlier than at sites with very low sedimentation rates. Based on this argument, vein mineral deposition at Site 504B should have ended or should be close to being completed. However, cessation of rapid deposition of secondary phases does not necessary imply that all chemical reactions within the crust end at the same time as well. There are probably a large number of reactions based on diffusive material transport which continue for a long time. These reactions may be nearly isochemical on the scale of a few meters, and do not substantially contribute to the bulk chemical budget between the oceanic crust and seawater.

Combining physical and chemical lines of evidence allows us to draw three conclusions regarding the duration of alteration as well as the type of alteration in the oceanic crust: (1) Rapid hydrothermal convection, which probably includes the most substantial amount of chemical exchange between the ocean crust and seawater, comprises a number of chemical exchange reactions which occur over a period of time. These processes approach completion at a crustal age of approximately 13 \pm 5 m.y., depending partially on sediment accumulation rates. (2) Alteration of the oceanic crust is very heterogeneous, particularly in the upper portion of Layer 2. Heterogeneous alteration may include convection of water through fault zones or horizontal zones of high permeability, such as the ones observed at Hole 504B (e.g., Anderson et al., 1982; Becker et al., 1983), but large portions of the crust are effectively sealed off from access by hydrothermal solutions. (3) Alteration of the oceanic crust along permeable zones, diffusive redistribution of elements within the crust, and possibly a slow dehydration during burial probably continue for a long time, possibly until subduction of the crust, at rather reduced rates of flow and chemical exchange.

It appears to be well demonstrated that hydrothermally driven convection and some chemical exchange in fact continue for very long times in the crust (Anderson and Hobart, 1976; Lawrence and Gieskes, 1981). However, the bulk exchange rates are probably rather low for all dissolved cations (Gieskes and Lawrence, 1981; McDuff, 1981).

The low ${ }^{87} \mathrm{Sr} /{ }^{86} \mathrm{Sr}$ ratios of carbonates from Hole 504B show that they precipitated from solutions which contained up to $80 \%$ of basalt Sr-component. Although this demonstrates that carbonates from Hole 504B cannot be used to constrain alteration ages, it provides the first evidence that vein carbonates can in fact be deposited from solutions which are markedly different from ambient seawater. This implies that sufficient $\mathrm{Ca}^{2+}$ is 
liberated during basalt alteration to allow precipitation of carbonates. The most important basalt alteration processes which provide $\mathrm{Ca}$ to the circulating hydrous solutions are alteration of basaltic glass and the breakdown of anorthitic feldspar. However, alteration of glass to palagonite is not only characterized by a loss of most of its $\mathrm{Ca}$, but also by a loss of $80-90 \%$ of the $\mathrm{Mn}, \mathrm{Na}$ and $\mathrm{P}$, and a loss of $50-70 \%$ of its $\mathrm{Si}, \mathrm{Al}, \mathrm{Mg}, \mathrm{Cr}, \mathrm{Hf}$, $\mathrm{Sc}$, Co and REE, which might also enter the circulating solutions (Ailyn-Pyzik and Sommer, 1981; Staudigel and Hart, 1983). Such complex basalt alteration reactions and precipitation of secondary phases make the composition of alteration solutions very different from original seawater composition. These changes are most drastic for dissolved cations, but they may also be significant with respect to the oxygen isotopic composition of the hydrothermal solutions.

The main reasons for the low water/rock ratios during alteration in Hole 504B are probably the rather high temperatures, resulting in more extensive reactions between seawater and basalt, and the sealing effect of the rapidly accumulating sediments. The latter was suggested as an explanation for the heat flow data (Langseth et al., 1982). However, there are some systematic structural differences between fast, intermediate, and slow-spreading ridges which might influence the flow of water as well. For example, slow-spreading ridges have a much rougher topography than fast-spreading ridges. The higher density of fault zones at slow-spreading ridges may enhance vertical fluid flow. Fast-spreading ridges probably are characterized by higher eruption rates which favor formation of more sheet flows and massive flows, whereas pillows are more abundant in environments with lower eruption rates (Staudigel and Schmincke, in press). The primary lithological differences might be responsible for differences in fluid flow. However, the structural characteristics at DSDP Hole 504B are still too poorly understood for us to be able appropriately to evaluate their significance to the circulation pattern of hydrous. solutions.

\section{ACKNOWLEDGMENTS}

This work was funded by the National Science Foundation (OCE 79-09457 to SRH), the Office of Naval Research (\# N0001-75-C-0291), the Lamont-Doherty Geological Observatory, and the Scripps Institution of Oceanography. We also are grateful to many colleagues and friends for fruitful discussions. Among those are J. Alt, K. Becker, P. Delaney, J. Edmond, J. Gieskes, J. Honnorez, M. Kastner, J. Lawrence, M. Mottl, S. Richardson, P. Robinson, and W. Seyfried. Samples analyzed in this study were obtained from DSDP/NSF through cooperation with M. Mottl and J. Honnorez and the shipboard scientific parties. Brian Taras picked and analyzed two calcites from Hole 504B; Pat Doyle identified, dated, and separated the fish teeth. Peggy Delaney, Joris Gieskes, and Jim Lawrence gave helpful reviews of this paper. Lisa Tauxe corrected the grammar and gave encouragement and support. Lamont-Doherty Geological Observatory publication number 3714 .

\section{REFERENCES}

Ailyn-Pyzik, I. B., and Sommer, S. E., 1981. Microscale chemical effects of low temperature alteration of DSDP basaltic glasses. $J$. Geophys. Res., 86:9503-9510.
Alt, J., and Honnorez, J., 1984. Alteration of the upper oceanic crust: DSDP Site 417: I Mineralogy and chemistry. Contrib. Mineral. Petrol. 87:149-169.

Anderson, R., and Hobart, M. A., 1976. The relation between heat flow, sediment thickness, and age in the Eastern Pacific. J. Geophys. Res., 81:2968-2989.

Anderson, R., Hobart, M. A., and Langseth, M., 1976. Geothermal convection through oceanic crust and sediments in the Indian Ocean. Science, 204:828-832.

Anderson, R. N., Honnorez, J., Becker, K., Adamson, A. C., Alt, J. C., Emmermann, R., Kempton, P. D., Kinoshita, H., Laverne, C., Mottl, M., and Newmark, R. L., 1982. DSDP Hole 504B, the first reference section over $1 \mathrm{~km}$ through layer 2 of the oceanic crust. Nature, 300:589-594.

Andrews, A. J., 1977. Low temperature fluid alteration of oceanic layer 2 basalts, DSDP Leg 37. Can. J. Earth Sci., 14:911-926.

Baker, P. A., Gieskes, J. M., and Elderfield, H., 1982. Diagenesis of carbonates in deep sea sediments-evidence from $\mathrm{Sr}-\mathrm{Ca}$ ratios and interstitial dissolved $\mathrm{Sr} 2+$ data. J. Sed. Petrol., 52:71-82.

Bass, M. N., 1976. Secondary minerals in oceanic basalts, with special reference to Leg 34, Deep Sea Drilling Project. In Yeats, R. S., Hart, S. R., et al., Init. Repts. DSDP, 34 Washington (U.S. Govt. Printing Office), 393-432.

Becker, K., Langseth, M. G., Von Herzen, R. P., and Anderson, R. N., 1983. Deep crustal geothermal measurements, Hole 504B, Costa Rica Rift. J. Geophys. Res., 88:3447-3457.

Becker, K., and Von Herzen, R. P., 1983. Heat transfer through the sediments of the mounds hydrothermal area, Galapagos Spreading Center at 86 deg. W. J. Geophys. Res., 88:995-1008.

Böhlke, J. K., Honnorez, J., and Honnorez-Guerstein, J., 1980. Alteration of basalts from Site 396B, Deep Sea Drilling Project: petrographic and mineralogic studies. Contrib. Mineral. Petrol., 73: 341-364.

Burke, W. H., Denison, R. E., Hetherington, E. A., Koepnik, R. B., Nelson, H. F., and Otto, J. B., 1982. Variation of seawater ${ }^{87} \mathrm{Sr} /$ ${ }^{86} \mathrm{Sr}$ throughout Phanerozoic time. Geology, 10:516-519.

Corliss, J. B., Dymond, J., Gordon, L. I., Edmond, J. M., Von Herzen, R. P., Ballard, R. D., Green, K., Williams, D., Bainbridge, A., Crane, K., and Van Andel, T. H., 1979. Submarine thermal springs on the Galapagos Rift. Science, 203: 1073-1083.

Crane, K., and Ballard, R. D., 1980. The Galapagos Rift at 86W: 4. Structure and morphology of hydrothermal fields and their relationships to the volcanic and tectonic processes of the rift valley. $J$. Geophys. Res., 85:1443-1454.

Donnelly, T., Francheteau, J., Bryan, W., Robinson, P. T., Flower, M. F. J., Salisbury, M., et al., 1980. Init. Repts. DSDP, 53, Pt. 2: Washington (U.S. Govt. Printing Office).

Edmond, J. M., Measures, C., McDuff, R. E., Chan, L. H., Collier, R., and Grant, B., 1979. Ridge Crest hydrothermal activity and the balances of the major and minor elements in the ocean: The Galapagos data. Earth Planet. Sci. Lett., 46:1-18.

Edmond, J. M., Measures, C., Magnum, B., Grant, B., Sclater, F. R. Collier, R., Hudson, A., Gordon, L. I., Corliss, J. B., 1979. On the formation of metal-rich deposits at ridge crests. Earth Planet Sci. Lett., 46:19-30.

Edmond, J. M., Van Damm, K. L., McDuff, R. E., and Measures, C. I., 1982. Chemistry of hot springs on the East Pacific Rise and their effluent dispersal. Nature, 297:187-191.

Elderfield, H., 1976. Hydrogenous material in marine sediments; excluding manganese nodules. In Riley, J. P., and Chester, R. (Eds.) Chemical Oceanography, 5: New York (Academic Press), 137-208.

Elderfield, H., and Gieskes, J. M., 1982. Sr isotopes in interstitial waters of marine sediments from Deep Sea Drilling Project Cores. Nature, 300:493-497.

Fodor, R. V., and Thiede, J., 1977. Volcanic breccia from DSDP Site 357: implications for the composition and origin of the Rio Grande Rise, South Atlantic Ocean. In Supko, P. R., Perch-Nielsen, K., et al., Init. Repts. DSDP, 39: Washington (U.S. Govt. Printing Office), 537-543.

Gieskes, J. M., and Lawrence, J. R., 1981. Alteration of volcanic matter in deep sea sediments: evidence from the chemical composition of interstitial waters from deep sea drilling cores. Geochim. Cosmochim. Acta, 45:1687-1703.

Hall, J. M., and Robinson, P. T., 1979. Deep crustal drilling in the North Atlantic Ocean. Science, 204:573-586. 
Hart, S. R., and Brooks, C., 1974. Clinopyroxene partitioning of K, Rb, Cs, Sr, and Ba. Geochim. Cosmochim. Acta, 38:1799-1806.

Hart, S. R., and Staudigel, H., 1978. Oceanic crust: age of hydrothermal alteration. Geophys. Res. Lett., 5:1009-1012.

1982. The control of alkalies and uranium in seawater by ocean crust alteration. Earth Planet. Sci. Lett., 58:202-212.

1983. Age of hydrothermal circulation on the Rio Grande Rise: Deep Sea Drilling Project Site 516. In Barker, P. F., Carlson, R. L., Johnson, D. A., et al., Init. Repts. DSDP, 72: Washington (U.S. Govt. Printing Office), 471-474.

Houtz, R., and Ewing, J., 1976. Upper crustal structure as a function of plate age. J. Geophys. Res., 81:2490-2498.

Jenkins, W. J., Edmond, J. M., and Corliss, J. B., 1978. Excess ${ }^{3} \mathrm{He}$ and ${ }^{4} \mathrm{He}$ in Galapagos submarine hydrothermal waters. Nature, 272 : 156-158.

Katz, A., and Matthews, A., 1977. The dolomitization of CaCO: an experimental study at $252-295^{\circ} \mathrm{C}$. Geochim. Cosmochim. Acta, 41: 297-308.

Kent, D., and Gradstein, F. M., in press. A Jurassic to Recent chronology. In Tucholke, R. R., and Vogt, P. (Eds.), The Western Atlantic Region (Vol. M). The Geology of North America: Boulder, Colorado (Geol. Soc. Am.).

Kinsman, D. J. J., and Holland, H. D., 1969. The Coprecipitation of $\mathrm{Sr}$ with aragonite between $16^{\circ} \mathrm{C}$ and $96^{\circ} \mathrm{C}$. Geochim. Cosmochim. Acta, 33:1-17.

Langseth, M. G., Cann, J. R., Natland, J. H., and Hobart, M., 1983, Geothermal phenomena at the Costa Rica Rift: background and objectives for drilling at Deep Sea Drilling Project Sites 501, 504, and 505. In Cann, J. R., Langseth, M. G., Honnorez, J., Von Herzen, R. P., White, S. M., et al., Init. Repts. DSDP, 69: Washington (U.S. Govt. Printing Office), 5-29.

Larson, R. L., and Hilde, T. W. C., 1975. A revised time scale of magnetic reversals for the early Cretaceous and late Jurassic. J. Geophys. Res., 80:2586-2594.

Lawrence, J. R., and Gieskes, J. M., 1981. Constraints on water transport and alteration in the oceanic crust from the isotopic composition of pore water. J. Geophys. Res., 86:7924-7934.
Lister, C. R. B., 1972. On the thermal balance of a mid-ocean ridge. Geophys. J. R. Astron. Soc., 26:515-535.

Lonsdale, P., 1977. Structural geomorphology of a fast spreading rise crest: the East Pacific Rise near 3.25S. Mar. Geophys. Res., 3: 251-293.

McDuff, R. E., 1981. Major cation gradients in DSDP interstitial waters: the role of diffusive exchange between seawater and upper oceanic crust. Geochim. Cosmochim, Acta, 45:1705-1713.

Mottl, M. J., 1983. Metabasalts, axial hot springs and the structure of hydrothermal systems at mid-ocean ridges. Bull. Geol. Soc. Am., 94:161-180.

Rea, D. K., 1975. A model for the formation of topographic feature of the East Pacific Rise crest. Geology, 3:77-80.

Richardson, S. H., Hart, S. R., and Staudigel, H. 1980. Vein mineral ages of old oceanic crust. J. Geophys. Res., 85:7195-7200.

Sclater, J. G., Crowe, J., and Anderson, R. N., 1976. On the Reliability of ocean heat flow averages. J. Geophys. Res., 81:2997-3006.

Sclater, J. G., Von Herzen, R. P., Williams, D. L., Anderson, R. N., and Klitgord, K. D., 1974. The Galapagos Spreading Center: heat flow on the north flank. Geophys. J. R. Astron. Soc., 38:609-626.

Staudigel, H., and Hart, S. R., 1983. Alteration of basaltic glass: processes and significance for the oceanic crust-seawater budget. Geochim. Cosmochim. Acta, 47:337-350.

Staudigel, H., Muehlenbachs, K., Richardson, S. H., and Hart, S. R., 1981. Agents of low-temperature ocean crust alteration. Contrib. Mineral. Petrol., 77:150-157.

Staudigel, H., Richardson, S. H., and Hart, S. R., 1981. Alteration of the oceanic crust: processes and timing. Earth Planet. Sci. Lett., 52:311-327.

Staudigel, H., and Schmincke, H. U., in press. The Pliocene seamount series of La Palma/Canary Islands. J. Geophys. Res.

Zindler, A., Staudigel, H., and Batiza, R., in press. Isotope and trace element geochemistry of young pacific seamounts: implications for the scale of upper mantle heterogeneity. Earth Planet. Sci. Lett.

Date of Initial Receipt: 17 November 1983

Date of Acceptance: 1 February 1984 